\title{
Maintaining connectivity: understanding the role of root order and mycelial networks in fine root decomposition of woody plants
}

\author{
Katilyn V. Beidler • Seth G. Pritchard
}

Received: 31 December 2016 / Accepted: 18 August 2017 / Published online: 21 September 2017

(C) Springer International Publishing AG 2017

\begin{abstract}
Background The predictive power of climate models is limited by an incomplete understanding of the controls on fine root decomposition and thus belowground carbon cycling. To more accurately model rates of decay, fine root heterogeneity needs to be addressed in fine root decomposition studies. Branching order integrates both structural and chemical properties that are important in indicating litter quality and decay rate.

Scope We discuss current views on the controls and patterns of fine root decomposition in combination with recent findings related to the effects of branching order and mycorrhizal decomposition. We examine the counterintuitive finding that nitrogen rich, lower order roots decompose more slowly than woody, higher order roots in temperate and subtropical forests.
\end{abstract}

Responsible Editor: Philippe Hinsinger.

Electronic supplementary material The online version of this article (https://doi.org/10.1007/s11104-017-3393-8) contains supplementary material, which is available to authorized users.

K. V. Beidler $(\bowtie)$

Department of Biology, Indiana University, Jordan Hall, Room 234, 1001 E. Third Street, Bloomington, IN 47405, USA e-mail: kbeidler@indiana.edu

K. V. Beidler · S. G. Pritchard Department of Biology, College of Charleston, 66 George Street, Charleston, SC 29401, USA
Conclusions We posit that slower decomposition of first and second compared to higher order roots might be caused by the poor carbon quality associated with higher concentrations of phenols in lower order roots or by inhibition of saprophytes by the mycorrhizal fungi that often preferentially inhabit these roots. Alternatively, apparent recalcitrance of lower order roots could be an experimental artifact caused by severing pre-mortem mycelial connections during sample processing, or exclusion of animals that graze fungal structures by the small mesh sizes characteristic of litterbags. To better predict the residence time of the carbon contained in the entire fine root pool, existing methods should be applied to individual root orders when practical. New methods for characterizing decomposition of undisturbed roots that have senesced naturally are greatly needed.

Keywords Fine root decomposition - Branching order . Mycorrhizal fungi $\cdot$ Litter quality $\cdot$ Myco-quality hypothesis

$\begin{array}{ll}\text { Abbreviations } \\ \text { AUF } & \text { Acid unhydrolyzable fraction } \\ \text { AET } & \text { Actual evapotranspiration } \\ \text { AM } & \text { Arbuscular mycorrhizae } \\ \text { ECM } & \text { Ectomycorrhizae } \\ \text { HR-MS } & \text { High resolution mass spectroscopy } \\ \text { NanoSIMS } & \text { Nano secondary ion mass spectrometry } \\ \text { SAP } & \text { Saprotrophic } \\ \text { SOM } & \text { Soil organic matter } \\ \text { SIP } & \text { Stabile isotope probing }\end{array}$


SRL Specific root length

STXM Synchrotron-based spectromicroscopy

TNC Total nonstructural carbohydrates

\section{Introduction}

Our lack of understanding of the controls of carbon residence time in soil was recently identified as the greatest impediment to modeling future climate changes (Friend et al. 2014). Fine root systems, the most distal roots traditionally defined as having diameters $<2.0 \mathrm{~mm}$, are a quantitatively important component of the global C cycle. Plants invest 22$67 \%$ of annual net primary productivity in fine roots which in turn transfer significant amounts of organic $\mathrm{C}$ into the soil. The soil $\mathrm{C}$ derived from root inputs could be as high as $50-80 \%$ of soil $\mathrm{C}$ in temperate and boreal forests (Clemmensen et al. 2013; Lynch et al. 2013). Because they are the structures which coordinate the flow of photoassimilate into soil with the absorption of mineral nutrients into plants, fine roots also serve as a mechanistically important link between $\mathrm{C}$ and other biogeochemical cycles, such as $\mathrm{N}$. The $\mathrm{N}$ contained in the fine root pool comprises one-seventh of all $\mathrm{N}$ held in terrestrial vegetation (Jackson et al. 1997) and the decomposition of fine roots contributes a substantial fraction of the nitrogen required both for the metabolism of the soil food web as well as plant productivity (Silver and Miya 2001; Fan and Jiang 2010). Therefore, the movement of carbon and nutrients from fine roots into the surrounding soil environment following senescence is crucial for understanding soil ecology and for modeling terrestrial biogeochemical cycling.

A large proportion of $\mathrm{CO}_{2}$ returned to the atmosphere from the soil surface is attributable to root litter decomposition, a process long thought to be controlled by litter quality. Litter quality generally refers to the physical and chemical traits of detritus that govern the ease with which decomposers mineralize nutrients from decaying materials (Corbeels 2001). In turn, both litter quality and soil biota are influenced by abiotic environmental conditions including air and soil temperature, soil structure, nutrient availability and $\mathrm{pH}$, and soil moisture (Wardle et al. 2004). Studies on decomposition have largely focused on aboveground litter (leaves and woody debris), despite the significant contribution of belowground litter (dead roots, root exudates, fungal and bacterial necromass) to SOM. Fine roots are thought to contribute as much as $40 \%$ of the litter produced annually (Vogt et al. 1990; Lukac 2012). However, reviews of the literature suggest that fewer than $5 \%$ of litter decomposition studies have focused on belowground decomposition, likely due to the difficulty associated with collecting fine root and fungal litter (Zhang et al. 2008; Aulen et al. 2012; Birouste et al. 2012).

Methodological challenges are confounded by uncertainty in "what defines a fine root," as root branching systems are extensive, architecturally complex and difficult to sample (Pregitzer 2002; Kong and Ma 2014; Beidler et al. 2015). Most commonly, fine roots have been defined as those roots that are less than two millimeters in diameter (McCormack et al. 2015). However, a few fine root studies have broadened this group to include roots ranging from $<0.5$ to $<5.0 \mathrm{~mm}$ in diameter (Majdi et al. 2001; Makita et al. 2009). This variability reflects the arbitrary nature of fine root designations or, less often, differences in diameter among plant species (Fitter 1996). Recent studies have shown that fine roots occupying different positions within a branching system (root orders), vary predictably in structure, function and thus rates of turnover and decomposition for several different long-lived perennial species (Pregitzer 2002; Wang et al. 2006; Guo et al. 2004, 2008a, 2008b; Valenzuela-Estrada et al. 2008; Fan and Guo 2010; Goebel et al. 2011; Xiong et al. 2013). For the purpose of this review, the most distal roots in a branching network are defined as first order roots. The extent to which order based classifications can be applied to annual and perennial plant species is unclear and more work needs to be done to demonstrate the generalizability of order-based patterns across plant taxa (Zobel 2016).

Despite detectable differences in lifespan, morphology and chemistry within the fine root guild, to our knowledge only five studies have measured rate of decomposition by branching order and only woody species have been represented (Fan and Guo 2010; Goebel et al. 2011; Xiong et al. 2013; Sun et al. 2016; Sun et al. forthcoming). Of the studies that incorporated order, all found evidence to support the claim that lower order roots decompose at a slower rate than higher order roots in several different temperate and sub-tropical tree species. Sun et al. (2013) found that the finest roots (roots $<0.5 \mathrm{~mm}$ in diameter) decomposed at a slower rate than roots with diameters ranging from $0.5-2 \mathrm{~mm}$, using both a litterbag and intact core technique. These 
results support the findings of McClaugherty et al. (1984) and Langley and Hungate (2003) in which nutrient rich thinner roots decomposed more slowly. These results seem counterintuitive, as lower order roots have a higher surface area to volume ratio, contain less lignin and are more nutrient rich, characteristics assumed to favor fast decomposition (Goebel et al. 2011; Wang et al. 2015).

The fate of organic matter in the rhizosphere depends on process rates of microorganisms, as bacteria and fungi are the primary decomposers of soil organic carbon (Hopkins and Gregorich 2005). Reduced decomposition of first order roots could therefore be the result of experimental artifacts associated with litterbags, a method that disrupts interactions between roots, soil fauna and rhizosphere microbes. The extent to which disruption of root connections with the rhizosphere influences rates of decomposition should vary by root order as the most distal first and second order roots are commonly colonized by mycorrhizal fungi. The extent of root colonization also differs with mycorrhizal association type. Ectomycorrhizal (ECM) fungi encase root tips forming an external mantle; in contrast, fungal structures are distributed more evenly within the first three branching orders of arbuscular mycorrhizal (AM) roots (Langley and Hungate 2003; Xia et al. 2010).

Mycelial networks, which consist of interconnected strands of cells or hyphae, could play a role in decomposition through resource transfer between living and decaying tissues. There is a growing body of evidence showing that some species of ECM fungi produce extracellular enzymes to degrade organic residues, obscuring the distinction between saprotroph and symbiont (Talbot et al. 2008; Lindahl and Tunlid 2015). The acquisition of nutrients from organic substrates via extracellular digestion, i.e. saprotrophic (SAP) nutrition, may be an effective means of reclaiming the $\mathrm{N}$ contained in mycorrhizal roots and mycelium (Read and Perez-Moreno 2003; Kuyper 2017). While AM fungi are capable of releasing phosphatases from extraradical hyphae and have been shown to hydrolyse organic P when grown in culture (Koide and Kabir 2000; Bucher 2007; Sato et al. 2015), the degree to which they produce extracellular enzymes to degrade SOM is thought to be minimal (Hodge 2017; Kuyper 2017). For these reasons, it seems clear that altering the rhizosphere environment and disturbing fungal symbionts is likely to influence the decomposition process but perhaps to a different extent in ECM compared to AM tree species, and in first compared to higher order roots (Dornbush et al. 2002; Fisk et al. 2011; Li et al. 2015).

It is important to differentiate between the degrees to which exogenous, compared to endogenous, tissue quality controls contribute to the decomposition process. In this review, we discuss the influence of root litter quality, environmental factors, and plant growth form on fine root decomposition by building off previous patterns identified by Silver and Miya's 2001 meta-analysis. We then explore the effect of root order and mycorrhizal fungi on fine root decomposition of woody plants. This review seeks to explain why decomposition is decoupled from traditional measures of litter quality in first order roots and draws attention to the role mycorrhizal fungi may be playing in the decomposition of fungal-root litter in forest ecosystems. It seems clear that determining whether the slower decomposition of first order roots is an experimental artifact, is attributable to their unique chemical properties, or is a product of mycorrhizal mediated decomposition will require new approaches to study individual root decomposition in situ. The synthesis concludes with a discussion of new techniques and methodological considerations that will lead to a refinement of decomposition theory.

\section{Factors that influence fine root decomposition}

Litter quality

Silver and Miya (2001) performed a meta-analysis (encompassing 30 locations and 40 species) of factors that regulate rates of root decomposition. The analysis showed that initial tissue chemistry explained the greatest proportion of variance in decomposition rate (85\%), while environmental variables, most notably temperature, precipitation and actual evapotranspiration (AET) played a secondary role. Since Silver and Miya's analysis, fine root decomposition studies have largely focused on the effects of litter quality on rate of decay and generally support the notion that litter quality regulates microbial activity and thus decomposition (Chen et al. 2001; Lemma et al. 2007). In general, decay rates of fine roots are positively correlated with initial concentrations of $\mathrm{Ca}, \mathrm{Mg}, \mathrm{Mn}, \mathrm{N}$ and $\mathrm{P}$ and negatively correlated with $\mathrm{C}: \mathrm{N}$, lignin: $\mathrm{N}$, cellulose, and phenolic compounds including tannins, and lignin (Berg et al. 1998; John et al. 2002; Jalota et al. 2006; Wang et al. 2010; Tong et al. 2012; García-Palacios et al. 2016; 
Guerrero-Ramírez et al. 2016; Roumet et al. 2016). However, exceptions have been reported in which initial root $\mathrm{C}: \mathrm{N}$, lignin: $\mathrm{N}$ and $\mathrm{N}$ content did not correlate with rate of decay (Poret et al. 2007; Hobbie 2008; Sun et al. 2013; Zhang and Wang 2015). It may be that C:N, lignin: $\mathrm{N}$ and $\mathrm{N}$ concentrations are not always the best predictors of root decomposition, given their dependence on the stage of decomposition, soil fertility and season of the year (Machinet et al. 2011; Talbot and Treseder 2012; Rinkes et al. 2016). Furthermore, it is likely that the specific nature of the molecules in which these elements reside, is also of critical importance.

The chemical features that determine the ease with which microorganisms decompose fine root litter change throughout the course of decomposition. Short term studies (6 months-2 years) report a two to three stage pattern of decomposition consisting of an initial stage of little or no decomposition (up to 30-90 days) followed by rapid mass loss (60-300 days) and then decomposition slows and level offs (300-600 days; John et al. 2002; Yang et al. 2004). Early stages of decomposition are thought to be driven by the concentrations of $\mathrm{N}$ and water soluble carbohydrates in plant residues (Domisch et al. 2000; Berg 2000). It has been demonstrated that rates of decomposition depend on both initial litter quality and the availability of soil $\mathrm{N}$ at early stages of decay (Mary et al. 1996). If microbial growth is not limited by nitrogen, the decomposition of root litter may be insensitive to initial $\mathrm{N}$ content and thus initial $[\mathrm{N}]$ may not always be useful in predicting fine root decomposition (Recous et al. 1995; Sall et al. 2007). Moreover, roots are colonized by soil microbes prior to decay which can temporarily increase $\mathrm{N}$ content and reduce root $\mathrm{C}: \mathrm{N}$ ratio; microbe-derived $\mathrm{N}$ decomposes differently than plant-derived $\mathrm{N}$ and may explain why $\mathrm{C}: \mathrm{N}$ ratios do not always predict rates of fine root decomposition (Abiven et al. 2005; Machinet et al. 2009).

Later stages of decomposition are thought to be more heavily influenced by interactions between $\mathrm{N}$ content and chemical form and components of root cell walls including lignin, cellulose, and suberin (John et al. 2002; Yang et al. 2004; Tripathi et al. 2006; Lemma et al. 2007). Increases in soil $\mathrm{N}$ availability can suppress decomposition of phenolic compounds contained within cell walls (Berg 2000; Wang et al. 2004). Additionally, the acid unhydrolyzable carbon fraction (AUF) which includes aliphatic compounds and lignin can confer resistance to decay by physically protecting $\mathrm{N}$-containing inner root tissues from microbial attack (Abiven et al.
2005; Fuji and Takeda 2010). Recent studies also highlight the importance of tannins; in high concentrations, tannins have the potential to inhibit enzymatic activity of microbes (Hättenschwiler and Vitousek 2000; Adamczyk et al. 2017). Condensed tannins, for example, were shown to have a strong negative effect on fine root decomposition in a nutrient rich temperate forest (Dong et al. 2016). The microbial compounds produced during decomposition are now thought to be the main contributors to stable SOM formation, rather than recalcitrant plant materials like lignin (Cotrufo et al. 2013). The rate and efficiency at which microorganisms decompose roots of varying quality and synthesize SOM is dependent on soil structure, moisture and temperature dynamics, in addition to microbial community composition (Schmidt et al. 2011; Frey et al. 2013; Kallenbach et al. 2016). It is the interaction between microbial products of decomposition, soil-clay mineralogy and climate which ultimately determine stabilization of root derived carbon in soils (Cotrufo et al. 2013; Lehmann and Kleber 2015).

Environmental factors

At the global scale, decay rate is positively related to precipitation and temperature, and negatively related to latitude and actual evapotranspiration (AET; Gholz et al. 2000; Laiho et al. 2004; Zhang et al. 2008). Temperature controls are thought to be more influential in temperate and boreal forests, while precipitation may be more important in tropical regions (Powers et al. 2009). Root decomposition rate increases from the poles to the tropics (Parton et al. 2007; Zhang and Wang 2015). Solly et al. (2014) found that at the regional scale edaphic factors including soil C:N ratio, temperature, and moisture explained more variation in rates of fine root decomposition than lignin: $\mathrm{N}$ ratios across forest ecosystems. Prieto et al. (2016) assessed fine root decomposition at the community level under standard conditions and found that roots from agroforestry communities decomposed faster than roots from natural forest communities. On average, fine roots from agroforestry communities had higher $\mathrm{N}$ and lower $\mathrm{C}$ and lignin concentrations compared to less disturbed forest sites; across communities, deeper roots decayed more slowly due to higher lignin to $\mathrm{N}$ ratios (Prieto et al. 2016). These findings suggest that the environmental changes associated with agricultural intensification may alter root litter quality and enhance decomposability, especially at shallow soil depths (Prieto et al. 2016). 
Changes in soil temperature and moisture can alter $\mathrm{C}$ allocation to roots, which in turn influences root litter quality. Water stress can lead to changes in root cell wall constituents, as plants increase concentrations of suberin (a biopolymer composed of aliphatic and aromatic compounds) and lignin, to mediate water loss from cells (Brunner et al. 2015). Increased amounts of suberin in root cell walls enhances the hydrophobic protection of tissues, slowing decomposition (Dignac and Rumpel 2013). García-Palacios et al. 2016 found decreased rates of $\mathrm{C}$ mineralization of fine root litter taken from an 11year rainfall exclusion experiment. Decreased decomposition was attributed to changes in the soil microbial community and reduced ability of microbes to break down recalcitrant $\mathrm{C}$ substrates such as phenolic compounds (García-Palacios et al. 2016). The increased protection or root $\mathrm{OM}$ brought on by environmental change and the corresponding effects on microbial metabolism demands further study (Dignac and Rumpel 2013).

Root traits and plant life form

To predict how decomposition will respond to environmental changes, recent literature has emphasized the use of trait-based approaches and the need for measurements that directly connect fine root traits to forest $\mathrm{C}$ and nutrient cycling (Iversen et al. 2017; McCormack et al. 2017). Fine root chemical and morphological traits vary across ecosystems and plant taxa, which in turn influences rates of decay as litter quality is a product of both the chemistry and structure of decomposing tissues (Dornbush et al. 2002; Birouste et al. 2012; Prieto et al. 2016). Among plant growth forms, fine roots of trees have larger diameters, higher $\mathrm{N}$ concentrations and lower specific root lengths (root length per unit dry mass; SRL) due to greater tissue densities (Freschet et al. 2017; Valverde-Barrantes et al. 2017). Whereas graminoids had the lowest $N$ content and tissue densities when compared to forbs, shrubs and trees (Valverde-Barrantes et al. 2017). For the different plant growth forms, rate of fine root decay increases in the following order: conifers $<$ broadleaf trees $<$ shrubs $<$ graminoids (Mao et al. 2011; Tong et al. 2012; Zhang and Wang 2015).

In a global analysis of fine root traits, Iversen et al. (2017) found that evergreen and deciduous broadleaf trees from temperate ecosystems had lower average C:N values when compared to needleleaf woody plants from the same ecosystem. It has been demonstrated that fine roots of deciduous tree species decompose more quickly than those of coniferous species (Mao et al. 2011; Tong et al. 2012). Furthermore, fine roots of gymnosperms tend to have larger diameters, denser tissues and decreased branching intensity compared to angiosperms; these differences likely contribute to the differential decomposability in these two plant groups (Liese et al. 2017). The traits associated with different ecological strategies of plants may also influence the rate at which their tissues decompose. There is some evidence that invasive species produce more labile litter than native species. However, Jo et al. (2016) found no difference in decomposition rates of fine roots between 23 native and 25 nonnative woody species in Eastern US deciduous forests. The same study found that woody $\mathrm{N}$-fixers had significantly lower root decomposition rates than non$\mathrm{N}$-fixers, likely due to higher concentrations of acidinsoluble residues (Jo et al. 2016). Given the differences in morphology and tissue chemistry among plant taxa, it is important to account for this variability and standardize the way we characterize fine roots.

\section{Role of branching order in fine root decomposition}

Branching position reflects differences in root age and tissue development, as newer more distal roots branch from older, more basal roots. Fitter (1982) introduced a morphometric approach to describe these architectural features based on topological models which rely on Strahler's stream ordering system (Fig. S1; Strahler 1957; Pregitzer et al. 2002; Valenzuela-Estrada et al. 2008). The most distal roots in a branching system are first order roots; the node from which two first order roots branch marks the location of a second order root, and so on (Strahler 1957; Guo et al. 2004). Lower order and higher order roots are thought to carry out different functions within the branching system (Guo et al. 2008a, 2008b). Lower order roots (1-2) function mainly in nutrient and water absorption, while higher order roots (3-5) are involved in transport, storage and production of lateral roots (Eissenstat et al. 2000). It has been suggested that short-lived, absorptive roots can collectively be thought of as a separate module (i.e., branching systems containing orders 1-3) comparable to a leaf, while longer-lived transportive roots are analogous to twigs (Kong and Ma 2014; McCormack et al. 2015). The extent to which roots can be classified by 
function differs among plant taxa and the criteria offered by McCormack et al. (2015) may not be appropriate for annual plants (Zobel 2016). Additionally, the division between roots involved in absorption and roots involved in transport can differ among and within species depending on environmental conditions (McCormack et al. 2016).

It is generally thought that root and stele diameter increase, whereas specific root length (the ratio of length to mass), cortex thickness, and mycorrhizal colonization all decrease with increasing branching order in fine roots of woody plants (Fig. 1; Guo et al. 2004; Hishi 2007; Long et al. 2013; Jia et al. 2013). Lower order roots are involved in water and nutrient uptake and have higher rates of respiration due to increased metabolic activity (Valenzuela-Estrada et al. 2008; Xia et al. 2010; Rewald et al. 2011; Jia et al. 2013). As a result, lower order roots contain higher concentrations of $\mathrm{N}$ and lower concentrations of total non-structural carbohydrates (TNC; Fan and Guo 2010). In general, root $C$ increases with branching order, consistent with storage and structural support functions. Accordingly, C:N, lignin and cellulose also increase with branching order (Fig. 1; Guo et al. 2004; Pregitzer et al. 2002; Hishi 2007; Jia et al. 2013). Fine root lifespan has been shown to increase with branching order, because higher order roots contain more secondary tissues and increased concentrations of suberin, protecting roots from pathogens and desiccation (Guo et al. 2008a; Hishi 2007; Xia et al. 2010; Adams et al. 2013). These differences in structure, function, and rhizosphere associates of different orders of living fine roots should translate into predictable patterns of fine root decomposition following senescence, but so far the ability to make such predictions has eluded the scientific community (Freschet et al. 2012; Roumet et al. 2016).

Tissue characteristics frequently used to predict leaf decomposition rates including $\mathrm{C}: \mathrm{N}$, lignin: $\mathrm{N}$, and $[\mathrm{N}]$, have proven surprisingly inadequate for predicting the decomposition of the finest roots. Moreover, the large surface area and small diameters of lower order roots are also characteristics that one would normally associate with rapid decomposition (Goebel et al. 2011; Xiong et al. 2013; Sun et al. forthcoming). Recent data suggest just the opposite, however, as the trend of slower decay of first order roots has now been demonstrated for several different tree species (Fan and Guo 2010; Goebel et al. 2011; Xiong et al. 2013; Sun et al. 2016; Sun et al. forthcoming). To reconcile discordance between theoretical predications and a growing body of empirical data, Fan and Guo (2010) proposed three hypotheses: (1) the
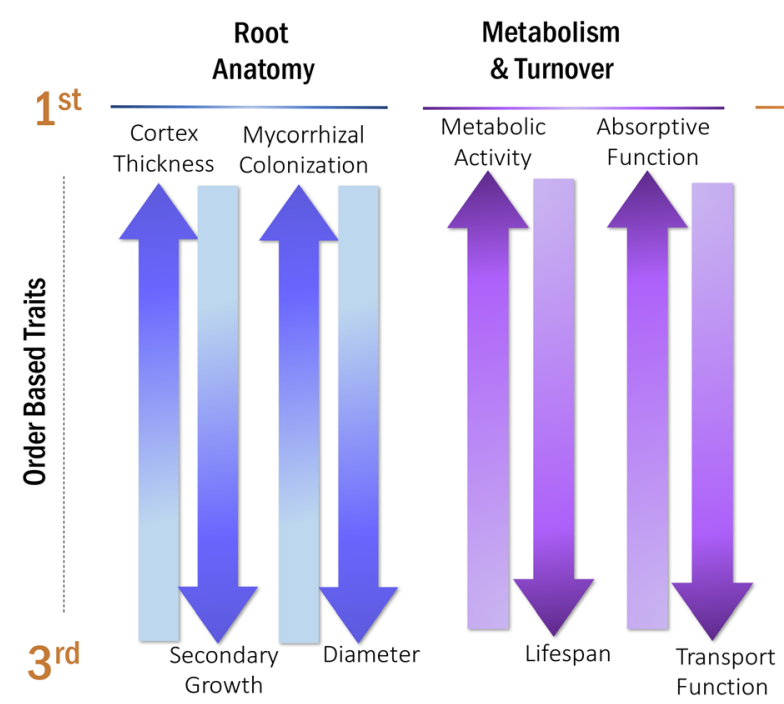

Fig. 1 Differences among the first three branching orders with respect to root anatomy, metabolism \& turnover, tissue chemistry and thus decomposition. The arrangement of arrows shows generalized patterns for traits related to branching position. $\mathrm{N}$ refers to Nitrogen and $\mathrm{C}: \mathrm{N}$ refers to the carbon to nitrogen ratio. Cross sections of decaying Pinus taeda roots demonstrate anatomical differences, which when combined with differences in initial

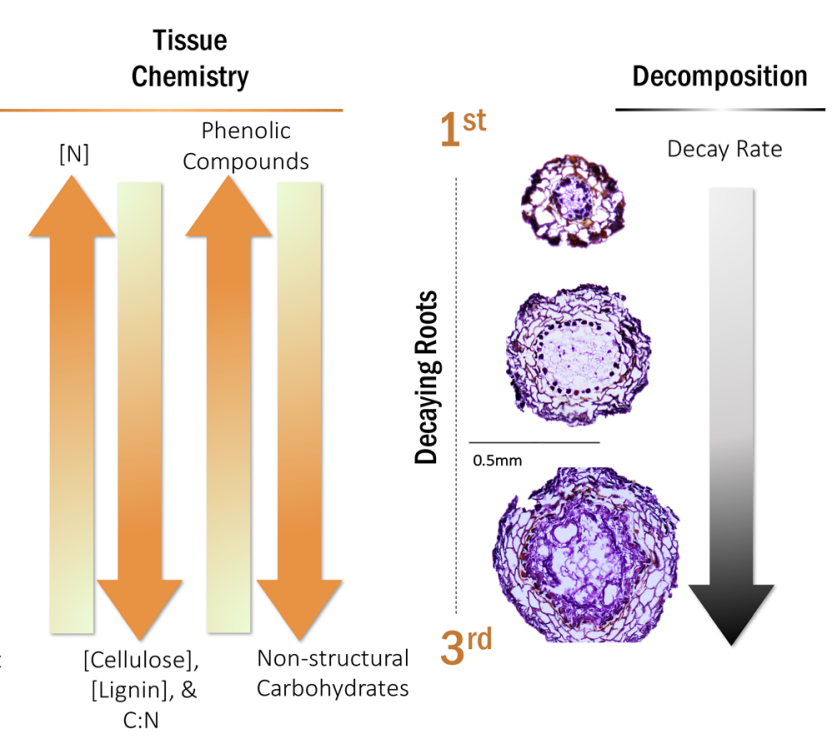

chemistry, influence rates of decay. The traits commonly associated with increased decomposability of tissues (greater concentrations of $\mathrm{N}$, decreased diameter, decreased $\mathrm{C}: \mathrm{N}$ ) do not seem to predict decomposition of the finest roots given that decay rate tends to increase with branching order. Adapted from McCormack et al. (2015) Fig. 4 
mycorrhizal hypothesis (Langley and Hungate 2003); (2) the C quality hypothesis (Guo et al. 2004); and (3) the N inhibition hypothesis (McClaugherty et al. 1984; Berg and McClaugherty 2008; Hobbie 2008). A fourth, more holistic explanation, termed the myco-quality hypothesis, joins the explanations for these counterintuitive results into one hypothesis as all three are likely interconnected through common links to nutrient dynamics. The following sections explore these explanations for the slower decomposition of lower order roots in detail and the potential for mycorrhizal-mediated decomposition of root tips. We add a fifth possible explanation that is based on the experimental artifacts inherent to how we go about conducting decomposition experiments. Regardless of the explanatory power these five mechanisms hold for explaining observed patterns of woody root decomposition, the predictability of fine root decomposition with respect to root order for herbaceous species may differ altogether.

\section{Explanations for slow decomposition of lower order roots}

The mycorrhizal hypothesis

The combination of plant and fungal tissue results in a unique biochemistry that may explain differences in decay rate between low and high order roots. Both $\mathrm{AM}$ and ECM roots have been shown to decompose more slowly than non-mycorrhizal and higher order roots (Langley and Hungate 2003; Fan and Guo 2010). The mycorrhizal hypothesis attributes slower rates of decomposition of first and second compared to higher order roots to the recalcitrant nature of fungal tissues, which encase ectomycorrhizal roots and form inside the roots of arbuscular mycorrhizal symbionts. In the past, the recalcitrant nature of fungal tissue was attributed to chitin, a long chain structural carbohydrate composed of $\mathrm{N}$-acetylglucosamine subunits (Bowman and Free 2006). This notion has been challenged in recent years, however. For example, Fernandez and Koide (2012) measured chitin concentrations in decaying ECM fungal tissues and demonstrated that chitin was no more resistant to decay than other fungal compounds. In fact, concentrations of chitin were associated with faster rates of decomposition (Fernandez and Koide 2012). These findings have been supported by Drigo et al. (2012), Zeglin et al. (2013) and Russell (2014), who report rapid declines in chitin concentrations within decomposing fungal tissues (Fernandez et al. 2016).

If the nature of fungal tissue makes lower order roots more resistant to decay, then ECM roots should decompose more slowly than AM roots (Fan and Guo 2010). ECM roots are sheathed in dense covering of layered hyphae and tend to contain a larger proportion of fungal tissue (20-40\%) compared to AM roots (3-17\%; Hepper 1977; Langley and Hungate 2003). Despite differences in intensity of colonization (number of root tips or percentage root length colonized by fungi), AM and ECM roots decomposed at similar rates in several different tree species, an observation that seems to refute the mycorrhizal hypothesis (Fan and Guo 2010; Soudzilovskaia et al. 2015; Sun et al. forthcoming).

It is possible that components of fungal cell walls other than chitin might contribute to the resistance of mycorrhizal roots to decay. For instance, AM fungi produce the hydrophobic glycoprotein, glomalin which may aid in waterproofing hyphae as they transport nutrients (Rilling et al. 2002; Fernandez et al. 2016). Like glomalin, ECM fungi produce hydrophobic proteins or hydrophobins that coat the outside of cell walls, making hyphae un-wettable (Fernandez et al. 2016). The hydrophobic nature of these fungal proteins also likely retards enzymatic decomposition. Additionally, the hydrophobic pigment, melanin which is located within fungal cell walls is thought to be important in regulating decomposition of ectomycorrhizal tissues (Fernandez and Koide 2014; Fernandez et al. 2016). ECM species differ with respect to the structure of their hyphal sheaths, the majority of which are hydrophobic; mantles can be made up of either loosely associated or tightly woven hyphae that form an outer cover comparable to a leaf's epidermis (Agerer 2006). The protective nature of the fungal mantle produced by ECM species, which varies with root branching order, may play an important role in deterring microbial decay.

\section{The C quality hypothesis}

The C quality hypothesis attributes slower decomposition of lower order roots to a higher acid insoluble or unhydrolyzable fraction (AUF) and decreased concentrations of TNC. The acid insoluble or unhydrolyzable fraction in lower order roots includes aliphatics (i.e. suberin), defensive compounds (i.e. alkaloids, phenylpropanoids and tannins) and lignin (Fan and Guo 2010; Xiong et al. 2013). Xiong et al. (2013) 
reported a negative correlation between decay rate and initial AUF in lower order roots for both subtropical and temperate tree species; no relationship was found between AUF and rate of decomposition in higher order roots. The slow decomposition of structural $\mathrm{C}$ contained in lower order roots may depend on complex cell wall chemistry, specifically linkages between polysaccharides and phenolic compounds (Moorhead et al. 2014). Plant litter is largely comprised of cell wall constituents in various states of decay and the composition of sugars in root cell walls can delineate the changeover from short to longer term decomposition (Bertrand et al. 2006; Moorhead and Sinsabaugh 2006; Moorhead et al. 2014). Additional work needs to be done to identify changes in carbohydrate composition and other aspects of cell wall chemistry as lower order roots decompose.

When present in esterified form, phenols can cross link with polysaccharides within cell walls and limit decomposition (Bertrand et al. 2006). Increased phenolic concentrations in the finest roots may be particularly important for conferring recalcitrance of first and second order roots. Phenolic quantity and quality recently have been found to differ significantly among root orders (Rasmann and Agrawal 2008; Adams and Eissenstat 2015; Wang et al. 2015; Zadworny et al. 2016). Sun et al. (forthcoming) investigated the drivers of decomposition for first order roots among 35 temperate tree species over the course of 6 years. Initial lignin and $\mathrm{N}$ concentrations did not explain the variability in decay rate. Decay rates were, however, significantly increased with increasing initial concentrations of TNC and significantly decreased with increasing initial concentrations of bound phenolics and condensed tannins. Overall, TNC and phenols seemed to have the greatest effect on decomposition of first order roots, despite occurring in disproportionately low amounts compared to other carbon compounds (Sun et al. forthcoming; Wang et al. 2015).

Lower order roots are nutrient dense, non-lignified tissues that would be expected to face higher herbivore and pathogen pressure than larger, less nutritious, and more heavily lignified structural roots (Sun et al. 2011). Based on this differential selection pressure exerted by herbivores, it is likely that the negative relationship between decomposition and AUF may be a by-product of the increased need for plants to defend the most metabolically active and nutrient-dense absorptive roots against other organisms present in the rhizosphere (Preston and Schmidt 2006; Xiong et al. 2013; Sun et al. forthcoming). In addition to tannins, other free or soluble phenols (i.e. phenolic acids, phenylpropanoids, quinones, and flavonoids) protect fine roots by decreasing palatability and increasing the rigidity of cell walls when bound to nonsoluble phenols (cell wall bound hydroxycinnamic acids, condensed tannins and lignin; Rispail et al. 2005; Wang et al. 2015). Larger diameter or denser roots (i.e., those with lower SRL) may contain more recalcitrant, mycorrhizal associated compounds (e.g. low concentration of soluble carbohydrates, a high AUF fraction) (Langley and Hungate 2003; Sun et al. 2013; Roumet et al. 2016).

Despite variability in tissue chemistry among species, AUFs and phenolic concentrations of first order roots seem to be good predictors of decomposition, this has still not been established for other root orders. Adams and Eissenstat (2015) measured concentrations of soluble phenols in relation to branching order for nine temperate tree species. They found that soluble phenolic content increased significantly with order, independent of species and mycorrhizal type (Adams and Eissenstat 2015). Alternatively, Wang et al. (2015) compared the first five root branching orders of the ericaceous shrub, Ardisia quinquegona and found that concentrations of phenolic compounds were higher and more seasonally variable in lower compared to higher order roots. Decreasing concentrations of both free and bound phenols with increasing branching order were reported (Wang et al. 2015). The discrepancy between these studies may have to do with extraction methods and/or site differences with respect to herbivore pressure. Clearly, more work is needed to resolve this issue.

\section{The $\mathrm{N}$ inhibition hypothesis}

Previous studies have shown that enhanced $\mathrm{N}$ conditions combined with a high AUF can slow decomposition in later stages of decay (Moorhead and Sinsabaugh 2006; Hobbie 2005, 2008). As stated previously, lower order roots contain greater concentrations of both $\mathrm{N}$ and acid insoluble compounds (Guo et al. 2004; Fan and Guo 2010; Sun et al. 2013). The N inhibition hypothesis accredits slower decomposition of lower order roots to condensation reactions between $\mathrm{N}$ and acid insoluble compounds, resulting in complexes that restrict microbial access to C (McClaugherty et al. 1984; Berg and McClaugherty 2008; Hobbie 2005, 2008; Fan and Guo 2010). As plant materials decay, microbial enzymes depolymerize organic substrates, potentially forming reactive amino and phenol groups that can also condense into nitrogen-rich complexes (Haider et al. 
1965; Kelley and Stevenson 1996; Davidson et al. 2003; Berg and McClaugherty 2008). It should be noted that much of the justification for the $\mathrm{N}$ inhibition hypothesis has come from studies which tested the effects of increased concentrations of soil inorganic N on decomposition of lignin-rich litter (Berg 2000; Hobbie 2005). Whether root $\mathrm{N}$ and products of microbial degradation combine to form persistent $\mathrm{N}$-phenol complexes warrants further study.

The extent to which root nitrogen concentration influences decomposition of lower order roots depends on soil $\mathrm{N}$ availability. Nitrogen addition may not impact lower order root decomposition if microbes are not initially limited by N. Furthermore, nitrogen fertilization has been demonstrated to suppress fungal growth and decrease phenol oxidase activity, in turn slowing decomposition (Burns et al. 2013; Rinkes et al. 2016). Plant litter containing increased concentrations of phenols may decompose more slowly in soils where $\mathrm{N}$ is readily available (Berg 2000; Wang et al. 2004; Rinkes et al. 2016). In a recent fertilization study, Sun et al. (2015) found that $\mathrm{N}$ fertilization inhibited decomposition of the first four branching orders of four temperate tree species over the course of four years. At the beginning of the study, the added $\mathrm{N}$ caused higher order roots to decompose more quickly, while lower order roots remained largely unaffected. In the latter stages of decomposition, $\mathrm{N}$ fertilization suppressed decomposition in both higher and lower order roots. Thomas et al. (2012) found that continual $\mathrm{N}$ deposition had little to no effect on the chemistry of lignin-derived phenols originating from root litter in sugar maple dominated hardwood forests. Nitrogen enrichment of soils may not enhance the recalcitrance of phenol complexes themselves, but instead influence decomposition through reductions in microbial biomass and decreased oxidative enzymatic activity (Rinkes et al. 2016).

The myco-quality hypothesis

The myco-quality hypothesis attempts to account for the slow turnover of the most distal order roots by combining aspects of the previous three hypotheses with current views on mycorrhizal interactions with saprotrophs, the dominant decomposers of plant litter in forests (Talbot et al. 2008). Initial colonization by mycorrhizal fungi could physically or chemically hinder subsequent colonization of lower order roots by saprotrophs, slowing decomposition through afterlife effects (Langley et al.
2006). Langley and Hungate (2003) predicted the trend of reduced decomposition in N-rich mycorrhizal roots, due in part to the production of fungal defensive compounds. ECM fungi protect roots from bacterial and fungal pathogens through the production of antimicrobial compounds, which can remain inside or close to root tissues upon senescence. Mycorrhizal colonization also reduces concentrations of non-structural carbohydrates in fine roots (Langley and Hungate 2003). The accumulation of secondary metabolites and reduction in soluble sugars brought on by mycorrhizal colonization influences root litter quality post-mortem and could deter colonization by free living saprotrophs. In addition to chemical antagonism, mycorrhizal fungi may regulate rates of decay by restricting saprotrophic (SAP) activity via competition for heterogeneously distributed soil nutrients (Gadgil and Gadgil 1975).

Competition for $\mathrm{N}$ is one of the mechanisms that may explain suppressed SAP decomposition in the presence of ECM fungi, i.e. the 'Gadgil Effect.' (Gadgil and Gadgil 1971, 1975; Koide and Wu 2003; Fernandez et al. 2015). The magnitude of the Gadgil effect is thought to be greatest in organic soil layers which are sensitive to changes in soil moisture and where competition for $\mathrm{N}$ is likely high (Bending 2003; Koide and Wu 2003). In boreal forests which are known to be N limited, ECM and SAP fungi are spatially separated. SAP fungi tend to colonize more recently shed litter at the forest floor surface and mycorrhizal fungi are more abundant in the underlying layers which contain older, more decomposed litter (Lindahl et al. 2007; Clemmensen et al. 2013; Bödeker et al. 2016). Whether this vertical separation is the result of competitive exclusion of saprotrophic fungi by ECM or niche differentiation needs to be addressed (Fernandez and Kennedy 2015).

Bödeker et al. 2016 tried to address this question by investigating the vertical positions of saprotrophic and ECM fungi in the soil profile and the potential for different fungal guilds to colonize substrates of varying quality. The results from their study support the idea that SAP and ECM fungi have overlapping fundamental niches, in that both were able to colonize the same substrates and their vertical separation in the soil is likely reinforced by competition for $\mathrm{N}$ (Bödeker et al. 2016). ECM fungi may have an advantage in decomposition at lower soil depths through early access to nutrients contained in senescing mycorrhizal roots and enzyme production subsidized by plant sugars (Cairney 
and Burke 1994; Langley and Hungate 2003; Lindahl and Tunlid 2015). Thus, ECM fungi may be primed to recycle $\mathrm{N}$ from root tissues they colonized and modified pre-mortem, but may be less efficient decomposers than saprotrophs, explaining slower rates of decomposition (Lindahl et al. 2002; Langley and Hungate 2003).

\section{Maintaining connectivity}

Mycelium can reserve a cache of nutrients for later redistribution by preventing resources from being intercepted by competing plants or immobilized in soil aggregates (Watkinson et al. 2005; Simard et al. 2012). Hyphal connections between living and decaying roots and bidirectional translocation in mycelial networks hint at the possibility for mycorrhizal participation in the decomposition of $\mathrm{N}$ rich lower order roots (Went and Stark 1968; Langley and Hungate 2003). It has been suggested that ECM fungi have saprotrophic capabilities, transforming SOM to acquire organic forms of nutrients (i.e. the nutrient mining by priming hypothesis as discussed by Kuyper 2017; Lindahl and Tunlid 2015). Whether ECM fungi act as "true" saprotrophs and obtain carbon from SOM for the purpose of building biomass is a point of contention in the literature, complicated by the fact that ECM fungal species vary widely in their ability to decompose organic substrates (Hodge 2017; Kuyper 2017; Pellitier and Zak 2017). It is a mistake to generalize saprotrophic function across ECM species; however, we should be careful not to discount the possible nutritional capabilities of ECM fungi with respect to root and fungal litter.

Laboratory cultures have demonstrated the potential for mycorrhizal fungi to decompose their own senescent tissues and ECM fungi have direct access to both decomposing roots and the sugars contained in living roots via their extensive hyphal networks (Kerley and Read 1998). During times of reduced photosynthetic supply from hosts, ECM fungi may induce decomposition of dying roots to allow the fungi to escape and find new hosts (Baldrian 2009). The presence of AM fungi has been shown to both enhance (Carillo et al. 2016; Gui et al. 2017) and suppress litter decomposition (Verbruggen et al. 2016; Hodge 2017). AM fungi are thought to play a more indirect role in decomposition via hyphal exudation, transport of inorganic nutrients away from decomposing substrates and corresponding changes in substrate quality (Hodge 2017). Future studies are needed to address the role mycorrhizae play in decomposition of SOM in a field setting. Whether/when ECM fungi are acting as obligate symbionts or facultative saprotrophs remains unclear (Baldrian 2009; Vaario et al. 2012; Kuyper 2017). Recently, it has been suggested that situational context is important in determining the extent to which substrates decompose (Schmidt et al. 2011). For first order roots to maintain situational context, they must decompose in the presence of intact rhizosphere soil, colonized by pre-mortem fungi (Li et al. 2015).

Fisk et al. (2011) disrupted the rhizosphere of roots decaying under root windows inset into the soil in an Eastern hardwood forest and found that the dominant fungal taxa changed due to the disturbance; rhizosphere species were replaced by bulk soil fungal species. Dornbush et al. (2002) decomposed recently senesced fine roots of silver maple using both litterbags and an intact core technique where roots are left to decompose within an intact soil core to limit rhizosphere disturbance. Mass loss was 23\% lower in litterbags and $\mathrm{N}$ release was $29 \%$ lower compared to intact cores (Dornbush et al. 2002). This difference in decay and nutrient dynamics was attributed to litterbaginduced alterations to decomposer dynamics. $\mathrm{Li}$ et al. (2015) found that fine root decomposition was twice as fast for roots decaying inside of intact soil cores compared to roots decaying in litterbags in a pine forest. The authors also detected changes in fungal communities colonizing decaying roots when the rhizosphere soil was left intact; ECM fungal taxa including: Boletales, Thelephorales and Cantharellales were detected more frequently in cores than litterbags. Correspondingly, greater release of $\mathrm{N}$ and $\mathrm{P}$ from roots was strongly correlated with increased abundance of Thelephorales and Cantharellales, hinting at the possibility that ECM fungi are mining nutrients from decaying fine roots (Lindahl and Tunlid 2015; Kuyper 2017). These studies suggest that slower decomposition of lower order roots may be an experimental artifact and draws attention to the change in microbial community composition that can occur when preparing roots for litterbags ( $\mathrm{Li}$ et al. 2015).

Order based studies are conducted using litterbags with restrictive mesh sizes to prevent movement of dissected root litter out of the bag and can alter moisture content inside of the bag; mesh sizes used included $50 \mu \mathrm{m}$ (Goebel et al. 2011), $100 \mu \mathrm{m}$ (Xiong et al. 2013), $120 \mu \mathrm{m}$ (Sun et al. 2013, 2016), and $500 \mu \mathrm{m}$ (Fan and Guo 2010). It is important to be cautious when 
comparing results of such studies with previous root decomposition studies that use litterbags with larger mesh sizes. Such small mesh sizes exclude macro and meso-fauna that would normally condition plant litter in ways that lead to faster microbial decomposition (González and Seastedt 2001; Sun et al. 2015; Frouz et al. 2015). Collembolans are known to feed on fungal hyphae which leads to fragmentation of roots tips, which in turn can disrupt the hydrophobic nature of hyphal coverings and increase decomposer access (Ekblad et al. 2013). Minirhizotron studies generally report that the finest roots with shorter longevity disappear from images (i.e., decompose) more quickly than larger diameter, higher order roots (Guo et al. 2008a; Fan and Guo 2010). Results from minirhizotrons seem to contradict the idea that the finest, most distal root tips persist in the soil longer than higher order roots (Pritchard et al. 2008; McCormack et al. 2012). The herbivores excluded in litterbag studies may explain this discrepancy, as roots tips in minirhizotron images may be eaten or damaged by soil animals (Lussenhop 1992; Steinaker and Wilson 2008).

\section{Methodological considerations for future studies}

While litterbag studies are the most common technique for quantifying decomposition, alternate methods such as the intact core approach and the use of root windows may provide research platforms from which to derive more reliable estimates of decomposition (Silver and Miya 2001; Sun et al. 2013; Li et al. 2015). These approaches limit rhizosphere disturbance and allow for functional comparisons among roots within the fine root branching system in situ (Dornbush et al. 2002; Fisk et al. 2011). Both the intact core and root window approaches maintain connectivity among belowground branching systems and do not require preliminary processing of root material (Dornbush et al. 2002). Root windows are temporary installations that house branching networks which can be tracked through time and later dissected by order. As a tradeoff, methods that conserve rhizosphere connections make it difficult to estimate initial mass and thus measure decay rates for individual samples. Mass loss can be estimated by tracking changes in population means through time; however, the number of cores or branching networks that would have to be destructively harvested to account for variability in root mass between locations and species would need to be determined ahead of time (Dornbush et al. 2002). While this a difficult and more time intensive approach than litterbags, it more accurately represents the decomposition process.

Most studies of decomposition of aboveground plant structures are conducted with tissues that have naturally senesced, such as fallen leaves (Berg and McClaugherty 2008). This is a potentially important point because plants living in $\mathrm{N}$ limited soils can resorb as much as $70 \%$ of leaf nitrogen during the senescence process (Nambiar and Fife 1991; Gordon and Jackson 2000; Langley and Hungate 2003; Han et al. 2013). While selecting senesced leaves to use for litter decomposition studies is straightforward, collecting fine roots that have senesced naturally is difficult or impossible. Furthermore, the season of collection can influence $\mathrm{N}$ content of lower order roots. Zadworny et al. (2015) found that $\mathrm{N}$ content of lower order roots increased during spring and summer and then declined at the end of the growing season coinciding with an increase in N concentration of the higher order transport roots in Quercus robur.

The extent to which resorption, or internal recycling of $\mathrm{N}$, is happening in fine root systems could have important implications for fine root litter quality. Although recovery of nutrients from senescing roots is not well documented, several recent studies suggest that it may be significant. For example, Kunkle et al. (2009) estimated that as much as $28 \%$ of fine $\operatorname{root} \mathrm{N}$ is resorbed from dying roots. Similarly, Freschet et al. (2010) observed a similar rate of $\mathrm{N}$ resorption $(27 \%)$ in fine roots of a large number of sub-arctic vascular plants. Clearly, such large differences in tissue quality in dead compared to living fine roots could significantly alter the results of fine root decomposition studies. Decomposition studies should consider the potential importance of tissue quality differences between living and dead fine roots and should try to account for the importance of intact linkages of ECM structures in dead or living fine roots and the mycelia stretching into bulk soil.

Future studies on fine root decomposition must begin to combine a fine-scale understanding of the molecular transformations undergone by various $\mathrm{N}$ and $\mathrm{C}$ containing compounds with knowledge of the role played by specific microbes as roots of different orders lose mass and change in quality during decomposition. Although this may seem complicated enough, it is becoming obvious that spatial and abiotic (soil minerology, 
temperature, $\mathrm{pH}$, and moisture content) context likely mediate such chemical transformations and cannot be ignored. Fortunately, new technologies have emerged and are beginning to be applied to rhizosphere processes that might make such an understanding possible in the not-to-distant future. For instance, advances in high throughput sequencing, combined with pipelines for managing the large volumes of data produced, now make it feasible to characterize the microbial community composition associated with different root orders through the course of decomposition using a metagenomics approach (Oburger and Schmidt 2016). Metatranscriptomics, metaproteomics, and metabolomics are rapidly developing techniques that make it possible to screen for changes in gene expression, characterize protein profiles, and understand activity of key metabolic pathways at the scale of the whole rhizosphere community associated with roots of different developmental orders (Oburger and Schmidt 2016; van Dam and Bouwmeester 2016).

Imaging combined with stable isotopic labeling approaches can be combined with the -omics techniques to track the fate of $\mathrm{C}$ and $\mathrm{N}$ atoms through the plantrhizosphere-soil continuum (Fig. 2). For instance, 13C labels either assimilated by leaves during photosynthesis, or $13 \mathrm{C}$ and $15 \mathrm{~N}$ injected into stems, can be tracked through pools of $\mathrm{C}$ and $\mathrm{N}$ containing compounds in roots during the time-course of decomposition using ultra high resolution mass spectroscopy (HR-MS) and then identified after being incorporated into nucleic acids of decomposers using stable isotope probing (SIP) techniques. Related techniques that can be used to track the movement of isotopic tracers from fine root pools into microbes and eventually into various SOM fractions include nanoSIMS (nano secondary ion mass spectrometry), and synchrotron-based spectromicroscopy (STXM; Keiluweit et al. 2012). Details on the potential of these techniques for unraveling the mysteries of fine root decomposition have been discussed in a number of recent publications (Ohno et al. 2010; Behrens et al. 2012; Keiluweit et al. 2012; van Dam and Bouwmeester 2016; Oburger and Schmidt 2016).

\section{Final thoughts}

The quantity and quality of carbon containing compounds in lower order roots could make a large

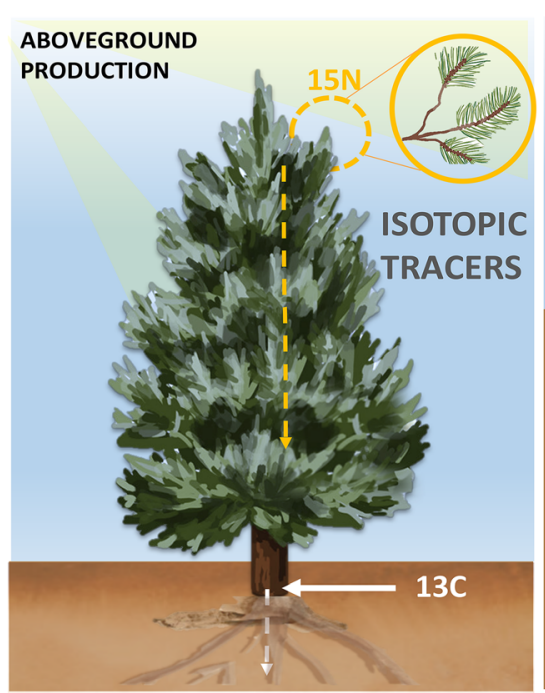

Fig. 2 In situ approaches to studying fine root decomposition that can be utilized in future studies. Field-based isotopic labeling $(15 \mathrm{~N}$ and 13C) approaches can be combined with the -omics techniques (metatranscriptomics, metaproteomics, and metabolomics) and mass spectroscopy (Mass Spec) to track the products of decomposition through the rhizosphere-soil continuum and link decomposer community structure to function. Maintaining rootrhizosphere connections allows us to accurately assess fine root contributions to soil organic matter (SOM) formation.
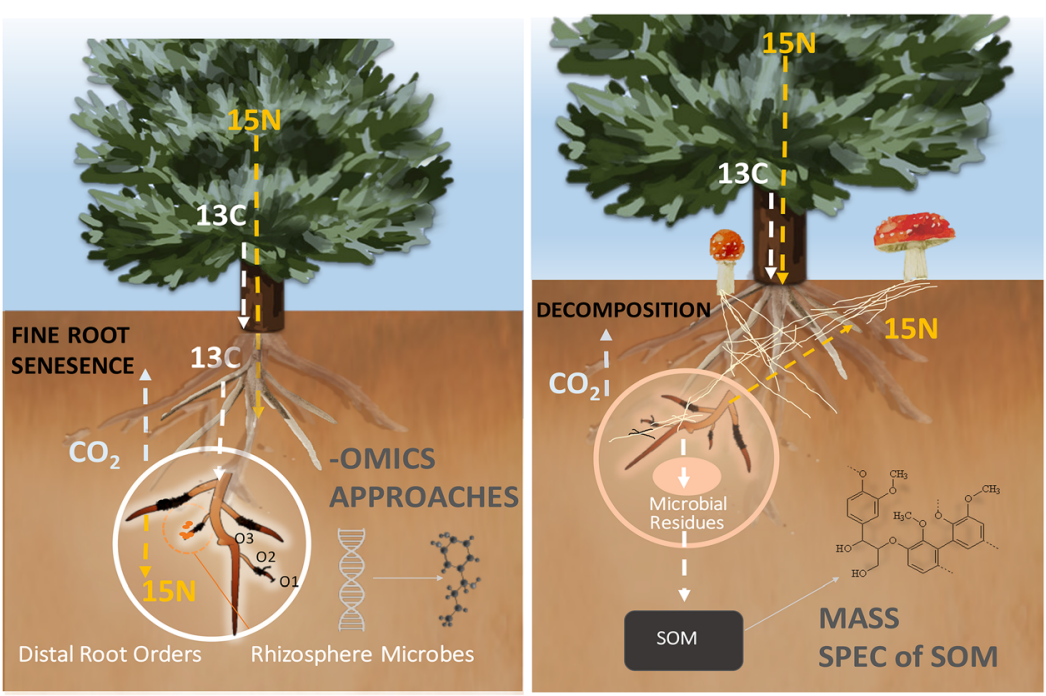

Furthermore, these techniques will allow for the identification of the community of decomposers which colonize roots of different branching orders (O1- Order 1, O2- Order 2 \& O3- Order 3). The ability to assess which members of the decomposer community are actively utilizing the $\mathrm{C}$ or $\mathrm{N}$ contained in decaying root and fungal substrates will shed light on the role mycorrhizal fungi play in decomposition (i.e. whether ECM fungi act as facultative saprotrophs) and why lower order roots decompose more slowly than their higher order counterparts 
Table 1 Remaining questions pertaining to fine root decomposition that should guide future research

Remaining questions

1. Does the trend of slower decomposition of lower order roots only apply to woody plants in temperate and subtropical forests?

- Is this trend observed across biomes?

- Is this true for herbaceous species to the extent they can be dissected by order?

- Is the slower decomposition of lower order roots an experimental artifact associated with litterbags?

2. Do mycorrhizal fungi compete with saprotrophic fungi for the nutrients contained within decomposing roots?

- If so, what are the soil conditions that encourage competition?

- Do arbuscular mycorrhizal fungi compete with saprotrophs?

3. Are mycorrhizal fungi obligate symbionts or latent saprotrophs (Kuyper 2017)?

- Are the saprotrophic activities of mycorrhizal fungi limited to boreal and temperate forests?

4. Are ECM fungi or SAP fungi the primary decomposers of fine roots?

- To what extent do ECM fungi utilize the $\mathrm{C}$ or $\mathrm{N}$ derived from decomposing roots and hyphae?

- Is there a seasonal trend to mycorrhizal decomposition?

5. What changes to $\mathrm{N}$ and $\mathrm{C}$-containing molecules occur during decomposition as live roots die and transition from litter to SOM and how do these transformations differ in lower order compared to higher order roots?

contribution to stable SOM formation if the majority of $\mathrm{N}$ in lower order roots is bound up in recalcitrant forms. The extent to which phenolic compounds contribute to delayed decomposition of fine roots and impact mycorrhizal symbionts requires further study. It may be that ECM fungi are capable of decomposing secondary metabolites to retrieve the $\mathrm{N}$ contained therein. This idea gained recent support by Terrer et al. (2016) who found that plant species colonized by ECM fungi were able to sustain increased growth under elevated concentrations of carbon dioxide despite low soil $\mathrm{N}$ availability a phenomenon that has also been reported by others (Drake et al. 2011). One possible mechanism for this sustained growth response is that ECM fungi, supplied with additional $\mathrm{C}$ from host plants, are able to mine recalcitrant compounds for $\mathrm{N}$ thereby increasing plant $\mathrm{N}$ uptake (Phillips et al. 2012; Terrer et al. 2016). To gain a more complete picture of the organisms and conditions driving the decomposition of the most distal root orders, there are a number of questions that require answers (Table 1). Although unraveling the complexities of decomposition of roots of different developmental orders promises to be methodologically challenging, the application of new techniques to this problem leaves us hopeful that a more holistic understanding of the controls of these processes will be achievable in the coming decade.

Acknowledgements We thank Courtney Murren, Allan Strand, Brien Beidler and Matt Nowlin for their feedback and editorial comments. We also would like to thank to the three anonymous reviewers for their helpful comments which greatly improved this manuscript.

\section{References}

Abiven S, Recous S, Reyes V, Oliver R (2005) Mineralization of C and $\mathrm{N}$ from root, stem and leaf residues in soil and role of their biochemical quality. Biol Fertil Soils 42:119-128

Adamczyk B, Karonen M, Adamczyk S et al (2017) Tannins can slow-down but also speed-up soil enzymatic activity in boreal forest. Soil Biol Biochem 107:60-67

Adams TS, Eissenstat DM (2015) On the controls of root lifespan: assessing the role of soluble phenolics. Plant Soil:301-308

Adams TS, McCormack ML, Eissenstat DM (2013) Foraging strategies in trees of different root morphology: the role of root lifespan. Tree Physiol 33:940-948

Agerer R (2006) Fungal relationships and structural identity of their ectomycorrhizae. Mycol Prog 5:67-107

Aulen M, Shipley B, Bradley R (2012) Prediction of in situ root decomposition rates in an interspecific context from chemical and morphological traits. Ann Bot 109:287-297

Baldrian P (2009) Ectomycorrhizal fungi and their enzymes in soils: is there enough evidence for their role of facultative soil saprotrophs? Oecologia 161:657-660

Behrens S, Kappler A, Obst M (2012) Linking environmental processes to the in situ functioning of microorganisms by high-resolution secondary ion mass spectrometry (NanoSIMS) and scanning transmission X-ray microscopy (STXM). Environ Microbiol 14:2851-2869

Beidler KV, Taylor BN, Strand AE et al (2015) Changes in root architecture under elevated concentrations of CO 2 and nitrogen reflect alternate soil exploration strategies. New Phytol:1153-1163

Bending GD (2003) Litter decomposition, ectomycorrhizal roots and the 'Gadgil' effect. New Phytol 158(2):228-229

Berg B (2000) Litter decomposition and organic matter turnover in northern forest soils. For Ecol Manag 133:13-22

Berg B, McClaugherty C (2008) Plant litter: decomposition, humus formation, carbon sequestration, third. Springer, Berlin

Berg B, Johansson M, Meentemeyer V, Kratz W (1998) Decomposition of tree root litter in a climatic transect of coniferous forests in northern Europe: a synthesis. Scand J For Res 13:402-412

Bertrand I, Chabbert B, Kurek B, Recous S (2006) Can the Biochemical Features and Histology of Wheat Residues Explain their Decomposition in Soil?. Plant and Soil 281(1-2):291-307 
Birouste M, Kazakou E, Blanchard A, Roumet C (2012) Plant traits and decomposition: are the relationships for roots comparable to those for leaves? Ann Bot 109:463-472

Bödeker ITM, Lindahl BD, Olson A, Clemmensen KE (2016) Mycorrhizal and saprotrophic fungal guilds compete for the same organic substrates but affect decomposition differently. Funct Ecol:1967-1978

Bowman SM, Free SJ (2006) The structure and synthesis of the fungal cell wall. BioEssays 28:799-808

Brunner I, Herzog C, Dawes MA, Arend M, Sperisen C (2015) How tree roots respond to drought. Front Plant Sci 6:547

Bucher M (2007) Functional biology of plant phosphate uptake at root and mycorrhiza interfaces. New Phytol 173:11-26

Burns RG, DeForest JL, Marxsen J et al (2013) Soil enzymes in a changing environment: current knowledge and future directions. Soil Biol Biochem 58:216-234

Cairney JWG, Burke RM (1994) Fungal enzymes degrading plant cell walls: their possible significance in the ectomycorrhizal symbiosis. Mycol Res 98:1345-1356

Carillo Y, Dijkstra FA, LeCain D, Pendall E (2016) Mediation of soil $\mathrm{C}$ decomposition by arbuscular mycorrhizal fungi in grass rhizospheres under elevated $\mathrm{CO}_{2}$. Biogeochemistry $127: 45-55$

Chen H, Harmon ME, Griffiths RP (2001) Decomposition and nitrogen release from decomposing woody roots in coniferous forests of the Pacific northwest: a chronosequence approach. Can J For Res 31:246-260

Clemmensen KE, Bahr A, Ovaskainen O et al (2013) Roots and associated fungi drive long-term carbon sequestration in boreal forest. Science 339(80):1615-1618

Corbeels M (2001) Plant litter and decomposition: general concepts and model approaches. NEW Work Proc, pp 124-129

Cotrufo MF, Wallenstein MD, Boot CM et al (2013) The microbial efficiency-matrix stabilization (MEMS) framework integrates plant litter decomposition with soil organic matter stabilization: do labile plant inputs form stable soil organic matter? Glob Chang Biol 19:988-995

Davidson EA, Chorover J, Dail DB (2003) A mechanism of abiotic immobilization of nitrate in forest ecosystems: the ferrous wheel hypothesis. Glob Chang Biol 9:228-236

Dignac MF, Rumpel C (2013) Organic matter stabilization and ecosystem functions. Biogeochemistry 112:1-6

Domisch T, Finér L, Laiho R et al (2000) Decomposition of scots pine litter and the fate of released carbon in pristine and drained pine mires. Soil Biol Biochem 32:1571-1580

Dong L, Mao Z, Sun T (2016) Condensed tannin effects on decomposition of very fine roots among temperate tree species. Soil Biol Biochem 103:489-492

Dornbush ME, Isenhart TM, Raich JW (2002) Quantifying fineroot decomposition: an alternative to buried litterbags. Ecology 83:2985-2990

Drake JE, Gallet-Budynek A, Hofmockel KS, Bernhardt ES, Billings SA, Jackson RB, Johnsen KS, Lichter J, McCarthy HR, McCormack ML, Moore DJP, Oren R, Palmroth S, Phillips RP, Pippen JS, Pritchard SG, Treseder KK, Schlesinger WH, DeLucia EH, Finzi AC (2011) Increases in the flux of carbon belowground stimulate nitrogen uptake and sustain the long-term enhancement of forest productivity under elevated CO2. Ecol Lett 14(4):349-357
Drigo B, Anderson IC, Kannangara GSK et al (2012) Rapid incorporation of carbon from ectomycorrhizal mycelial necromass into soil fungal communities. Soil Biol Biochem 49:4-10

Eissenstat DM, Wells CE, Yanai RD, Whitbeck JL (2000) Building roots in a changing environment: implications for root longevity. New Phytol 147:33-42

Ekblad A, Wallander H, Godbold DL et al (2013) The production and turnover of extramatrical mycelium of ectomycorrhizal fungi in forest soils: role in carbon cycling. Plant Soil 366: $1-27$

Fan P, Guo D (2010) Slow decomposition of lower order roots: a key mechanism of root carbon and nutrient retention in the soil. Oecologia 163:509-515

Fan P, Jiang Y (2010) Nitrogen dynamics differed among the first six root branch orders of Fraxinus mandshurica and Larix gmelinii during short-term decomposition. J Plant Res 123: 433-438

Fernandez CW, Kennedy PG (2015) Revisiting the "Gadgil effect": do interguild fungal interactions control carbon cycling in forest soils? New Phytol 209:1382-1394

Fernandez CW, Koide RT (2012) The role of chitin in the decomposition of ectomycorrhizal fungal litter. Ecology 93:24-28

Fernandez CW, Koide RT (2014) Initial melanin and nitrogen concentrations control the decomposition of ectomycorrhizal fungal litter. Soil Biol Biochem 77:150-157

Fernandez CW, Langley JA, Chapman S et al (2016) The decomposition of ectomycorrhizal fungal necromass. Soil Biol Biochem 93:38-49

Fisk MC, Fahey TJ, Sobieraj JH et al (2011) Rhizosphere disturbance influences fungal colonization and community development on dead fine roots. Plant Soil 341:279-293

Fitter AH (1982) Morphometric analysis of root systems: application of the technique and influence of soil fertility on root system development in two herbaceous species. Plant Cell Environ 5:313-322

Fitter AH (1996) Characteristics and functions of root systems. In: Waisel Y, Eschel A, Kafkafi U (eds) Plant roots: the hidden half, 2nd edn. Marcel Dekker, New York, pp 1-20

Freschet GT, Aerts R, Cornelissen JHC (2012) Multiple mechanisms for trait effects on litter decomposition: moving beyond home-field advantage with a new hypothesis. J Ecol 100(3):619-630

Freschet GT, Cornelissen JHC, van Logtestijn RSP, Aerts R (2010) Evidence of the "plant economics spectrum" in a subarctic flora. J Ecol 98:362-373

Freschet G, Valverde-Barrantes OJ, Tucker CM et al (2017) Climate, soil and plant functional types as drivers of global fine-root trait variation. J Ecol:1-15

Frey SD, Lee J, Melillo JM, Six J (2013) The temperature response of soil microbial efficiency and its feedback to climate. Nat Clim Chang 3:395-398

Friend AD, Lucht W, Rademacher TT et al (2014) Carbon residence time dominates uncertainty in terrestrial vegetation responses to future climate and atmospheric $\mathrm{CO} 2$. Proc Natl Acad Sci U S A 111:3280-3285

Frouz J, Roubíckova A, Hedenec P, Tajovský K (2015) Do soil fauna really hasten litter decomposition? A meta-analysis of enclosure studies. Eur J Soil Biol 68:18-24

Fuji S, Takeda H (2010) Dominant effects of litter substrate quality on the difference between leaf and root 
decomposition process above- and belowground. Soil Biol Biochem 42:2224-2230

Gadgil RL, Gadgil PD (1971) Mycorrhiza and litter decomposition. Nature 233:133

Gadgil RL, Gadgil PD (1975) Suppression of litter decomposition by mycorrhizal roots of Pinus radiata. N Z J For Sci 5:33-41

García-Palacios P, Prieto I, Ourcival JM, Hättenschwiler S (2016) Disentangling the litter quality and soil microbial contribution to leaf and fine root litter decomposition responses to reduced rainfall. Ecosystems 19:490-503

Gholz HL, Wedin DA, Smitherman SM et al (2000) Long-term dynamics of pine and hardwood litter in contrasting environments: toward a global model of decomposition. Glob Chang Biol 6:751-765

Goebel M, Hobbie SE, Bulaj B et al (2011) Decomposition of the finest root branching orders: linking belowground dynamics to fine-root function and structure. Ecol Monogr 81:89-102

González G, Seastedt TR (2001) Soil fauna and plant litter decomposition in tropical and subalpine forests. Ecology 82:955-964

Gordon WS, Jackson RB (2000) Nutrient concentrations in fine roots. Ecology 81:275-280

Guerrero-Ramírez NR, Craven D, Messier C et al (2016) Root quality and decomposition environment, but not tree species richness, drive root decomposition in tropical forests. Plant Soil 404:125-139

Gui H, Hyde K, Xu J, Mortimer P (2017) Arbuscular mycorrhiza enhance the rate of litter decomposition while inhibiting soil microbial community development. Sci Rep 7:42184

Guo DL, Mitchell RJ, Hendricks JJ (2004) Fine root branch orders respond differentially to carbon source-sink manipulations in a longleaf pine forest. Oecologia 140:450-457

Guo D, Mitchell RJ, Withington JM et al (2008a) Endogenous and exogenous controls of root life span, mortality and nitrogen flux in a longleaf pine forest: root branch order predominates. J Ecol 96:737-745

Guo D, Li H, Mitchell RJ et al (2008b) Fine root heterogeneity by branch order: exploring the discrepancy in root turnover estimates between minirhizotron and carbon isotopic methods. New Phytol 177:443-456

Haider K, Frederick LR, Flaig W (1965) Reactions between amino acid compounds and phenols during oxidation. Plant Soil 22: 49-64

Han W, Tang L, Chen Y, Fang J (2013) Relationship between the relative limitation and resorption efficiency of nitrogen vs phosphorus in woody plants. PLoS One 8:e83366

Hättenschwiler S, Vitousek PM (2000) The role of polyphenols in terrestrial ecosystem nutrient cycling. Trends Ecol Evol 15: 238-243

Hepper CM (1977) A colorimetric method for estimating vesicular-arbuscular mycorrhizal infection in roots. Soil Biol Biochem 9:15-18

Hishi T (2007) Heterogeneity of individual roots within the fine root architecture: causal links between physiological and ecosystem functions. J For Res 12:126-133

Hobbie SE (2005) Contrasting effects of substrate and fertilizer nitrogen on the early stages of litter decomposition. Ecosystems 8:644-656

Hobbie SE (2008) Nitrogen effects on decomposition: a five-year experiment in eight temperate sites. Ecology 89:2633-2644
Hodge A (2017) Accessibility of inorganic and organic nutrients for mycorrhizas. In: Johnson NC (ed) Mycorrhizal mediation of soil: fertility, structure, and carbon storage. Elsevier, pp 129-144

Hopkins DW, Gregorich EG (2005) Decomposition of residues and loss of the $\delta$-endotoxin from transgenic $(\mathrm{Bt})$ corn ( Zea mays L.) in soil. Can J Soil Sci 85:19-26

Iversen CM, Mccormack ML, Powell AS et al (2017) A global fine-root ecology database to address below-ground challenges in plant ecology. New Phytol 215:15-26

Jackson RB, Mooney HA, Schulze ED (1997) A global budget for fine root biomass, surface area, and nutrient contents. Proc Natl Acad Sci U S A 94:7362-7366

Jalota RK, Dalal RC, Harms BP et al (2006) Effects of litter and fine root composition on their decomposition in a Rhodic Paleustalf under different land uses. Commun Soil Sci Plant Anal 37:1859-1875

Jia S, McLaughlin NB, Gu J et al (2013) Relationships between root respiration rate and root morphology, chemistry and anatomy in Larix gmelinii and Fraxinus mandshurica. Tree Physiol 33:579-589

Jo I, Fridley JD, Frank DA (2016) More of the same? In situ leaf and root decomposition rates do not vary between 80 native and nonnative deciduous forest species. New Phytol 209: 115-122

John B, Pandey HN, Tripathi RS (2002) Decomposition of fine roots of Pinus kesiya and turnover of organic matter, $\mathrm{N}$ and $\mathrm{P}$ of coarse and fine pine roots and herbaceous roots and rhizomes in subtropical pine forest stands of different ages. Biol Fertil Soils 35:238-246

Kallenbach CM, Frey SD, Grandy AS (2016) Direct evidence for microbial-derived soil organic matter formation and its ecophysiological controls. Nat Commun 7:13630

Keiluweit M, Bougoure JJ, Zeglin LH et al (2012) Nano-scale investigation of the association of microbial nitrogen residues with iron (hydr)oxides in a forest soil O-horizon. Geochim Cosmochim Acta 95:213-226

Kelley KR, Stevenson FJ (1996) Forms and nature of organic N in soil. Fertil Res 42:1-11

Kerley SJ, Read DJ (1998) The biology of mycorrhiza in the Ericaceae XX. Plant and mycorrhizal necromass as nitrogenous substrates for the ericoid mycorrhizal fungus Hymenoscyphus ericae and its host. New Phytol 139: 353-360

Koide RT, Kabir Z (2000) Extraradical hyphae of the mycorrhizal fungus Glomus intraradices can hydrolyse organic phosphate. New Phytol 148:511-517

Koide RT, Wu T (2003) Ectomycorrhizas and retarded decomposition in a Pinus resinosa plantation. New Phytol 158: 401-407

Kong D, Ma C (2014) Acquisition of ephemeral module in roots: a new view and test. Sci Rep 4:4-7

Kunkle JM, Walters MB, Kobe RK (2009) Senescence-related changes in nitrogen in fine roots: mass loss affects estimation. Tree Physiol 29:715-723

Kuyper TW (2017) Carbon and energy sources of mycorrhizal fungi: obligate symbionts or latent saprotrophs? In: Johnson NC (ed) Mycorrhizal mediation of soil: fertility, structure, and carbon storage. Elsevier, pp 357-371

Laiho R, Laine J, Trettin CC, Finér L (2004) Scots pine litter decomposition along drainage succession and soil nutrient 
gradients in peatland forests, and the effects of inter-annual weather variation. Soil Biol Biochem 36:1095-1109

Langley JA, Hungate BA (2003) Mycorrhizal controls on belowground litter quality. Ecology 84:2302-2312

Langley AJ, Chapman SK, Hungate BA (2006) Ectomycorrhizal colonization slows root decomposition: the post-mortem fungal legacy. Ecol Lett 9:955-959

Lehmann J, Kleber M (2015) The contentious nature of soil organic matter. Nature:1-9

Lemma B, Nilsson I, Kleja DB et al (2007) Decomposition and substrate quality of leaf litters and fine roots from three exotic plantations and a native forest in the southwestern highlands of Ethiopia. Soil Biol Biochem 39:2317-2328

Li A, Fahey TJ, Pawlowska TE et al (2015) Fine root decomposition, nutrient mobilization and fungal communities in a pine forest ecosystem. Soil Biol Biochem 83:76-83

Liese R, Alings K, Meier IC (2017) Root branching is a leading root trait of the plant economics Spectrum in temperate trees. Front Plant Sci 8:1-12

Lindahl BD, Tunlid A (2015) Ectomycorrhizal fungi - potential organic matter decomposers, yet not saprotrophs. New Phytol 205:1443-1447

Lindahl BD, Taylor AFS, Finlay RD (2002) Defining nutritional constraints on carbon cycling in boreal forests - towards a less "phytocentric" perspective. In: Plant and Soil. pp 123-135

Lindahl BD, Ihrmark K, Boberg J et al (2007) Spatial separation of litter decomposition and mycorrhizal nitrogen uptake in a boreal forest. New Phytol 173:611-620

Long Y, Kong D, Chen Z, Zeng H (2013) Variation of the linkage of root function with root branch order. PLoS One 8:e57153

Lukac M (2012) Fine root turnover. In: measuring roots: an updated approach, pp 363-373

Lussenhop J (1992) Mechanisms of microarthropod-microbial interactions in soil. Adv Ecol Res 23:1-33

Lynch DJ, Matamala R, Iversen CM et al (2013) Stored carbon partly fuels fine-root respiration but is not used for production of new fine roots stored carbon partly fuels fine-root respiration but is not used for production of new fine roots. New Phytol 199:420-430

Machinet GE, Bertrand I, Chabbert B et al (2009) Soil biodegradation of maize root residues: interaction between chemical characteristics and the presence of colonizing micro-organisms. Soil Biol Biochem 41:1253-1261

Machinet GE, Bertrand I, Barrière Y et al (2011) Impact of plant cell wall network on biodegradation in soil: role of lignin composition and phenolic acids in roots from 16 maize genotypes. Soil Biol Biochem 43:1544-1552

Majdi H, Damm E, Nylund J (2001) Longevity of Mycorrhizal roots depends on branching order and nutrient availability. New Phytol 150:195-202

Makita N, Hirano Y, Dannoura M et al (2009) Fine root morphological traits determine variation in root respiration of Quercus serrata. Tree Physiol 29:579-585

Mao R, Zeng DH, Li LJ (2011) Fresh root decomposition pattern of two contrasting tree species from temperate agroforestry systems: effects of root diameter and nitrogen enrichment of soil. Plant Soil 347:115-123

Mary B, Recous S, Darwis D, Robin D (1996) Interaction between decomposition of plant residues and $\mathrm{N}$ cycling in soil. Plant Soil 181:71-82
McClaugherty CA, Aber JD, Melillo JM (1984) Decomposition dynamics of fine roots in forested ecosystems. Oikos 42:378-386

McCormack LM, Adams TS, Smithwick EAH, Eissenstat DM (2012) Predicting fine root lifespan from plant functional traits in temperate trees. New Phytol 195:823-831

McCormack LM, Dickie IA, Eissenstat DM et al (2015) Redefining fine roots improves understanding of belowground contributions to terrestrial biosphere processes. New Phytol 207:505-518

McCormack LM, Iversen CM, Eissenstat DM (2016) Moving forward with fine-root definitions and research. New Phytol 212:313

McCormack ML, Guo D, Iversen CM, Chen W, Eissenstat DM, Fernandez CW, Li L, Ma C, Ma Z, Poorter H, Reich PB, Zadworny M, Zanne A (2017) Building a better foundation: improving root-trait measurements to understand and model plant and ecosystem processes. New Phytol 215(1):27-37

Moorhead DL, Sinsabaugh RL (2006) A theoretical model of litter decay and microbial interaction. Ecol Monogr 76:151-174

Moorhead D, Lashermes G, Recous S, Bertrand I (2014) Interacting microbe and litter quality controls on litter decomposition: a modeling analysis. PLoS One 9:1-12

Nambiar EKS, Fife DN (1991) Nutrient retranslocation in temperate conifers. Tree Physiol 9:185-207

Oburger E, Schmidt H (2016) New methods to unravel Rhizosphere processes. Trends Plant Sci 21:243-255

Ohno T, He Z, Sleighter RL et al (2010) Ultrahigh resolution mass spectrometry and indicator species analysis to identify marker components of soil- and plant biomass-derived organic matter fractions. Environ Sci Technol 44:8594-8600

Parton W, Silver WL, Burke IC, Grassens L, Harmon ME, Currie WS, King JY, Adair EC, Brandt LA, Hart SC, Fasth B (2007) Global-Scale Similarities in Nitrogen Release Patterns During Long-Term Decomposition. Science 315(5810): 361-364

Pellitier PT, Zak DR (2017) Ectomycorrhizal fungi and the enzymatic liberation of nitrogen from soil organic matter: why evolutionary history matters. New Phytol. https://doi. org/10.1111/nph.14598

Phillips RP, Meier IC, Bernhardt ES et al (2012) Roots and fungi accelerate carbon and nitrogen cycling in forests exposed to elevated CO2. Ecol Lett 15:1042-1049

Poret N, Twilley RR, Rivera-Monroy VH, Coronado-Molina C (2007) Belowground decomposition of mangrove roots in Florida coastal everglades. Estuar Coasts 30:491-496

Powers JS, Montgomery RA, Adair EC et al (2009) Decomposition in tropical forests: a pan-tropical study of the effects of litter type, litter placement and mesofaunal exclusion across a precipitation gradient. J Ecol 97:801-811

Pregitzer KS (2002) Fine roots of trees - a new perspective. New Phytol 154:267-270

Pregitzer K, DeForest J, Burton AJ et al (2002) Fine root architecture of nine north American trees. Ecol Monogr 72:293-309

Preston CM, Schmidt MWI (2006) Black (pyrogenic) carbon: a synthesis of current knowledge and uncertainties with special consideration of boreal regions. Biogeosciences 3:397-420

Prieto I, Stokes A, Roumet C (2016) Root functional parameters predict fine root decomposability at the community level. J Ecol 104:725-733 
Pritchard SG, Strand AE, McCormack ML et al (2008) Fine root dynamics in a loblolly pine forest are influenced by free-air$\mathrm{CO}_{2}$-enrichment: a six-year-minirhizotron study. Glob Chang Biol 14:588-602

Rasmann S, Agrawal A (2008) In defense of roots: a research agenda for studying plant resistance to belowground herbivory. Plant Physiol 146:875-880

Read DJ, Perez-Moreno J (2003) Mycorrhizas and nutrient cycling in ecosystems - a journey towards relevance? New Phytol 157:475-492

Recous S, Robin D, Darwis D, Mary B (1995) Soil inorganic N availability: effect on maize residue decomposition. Soil Biol Biochem 27:1529-1538

Rewald B, Ephrath JE, Rachmilevitch S (2011) A root is a root is a root? Water uptake rates of citrus root orders. Plant Cell Environ 34:33-42

Rilling MC, Steinberg PD (2002) Glomalin production by an arbuscular mycorrhizal fungus: a mechanism of habitat modification?. Soil Biol Biochem 34(9):1371-1374

Rinkes ZL, Bertrand I, Amin BAZ et al (2016) Nitrogen alters microbial enzyme dynamics but not lignin chemistry during maize decomposition. Biogeochemistry 128:171-186

Rispail N, Morris P, Webb KJ (2005) Phenolic compounds: extraction and analysis. Lotus Japonicus handbook, In, pp 349-354

Roumet C, Birouste M, Picon-Cochard C et al (2016) Root structure-function relationships in 74 species: evidence of a root economics spectrum related to carbon economy. New Phytol 210:815-826

Russell AE (2014) Unexpected effects of chitin, cellulose, and lignin addition on soil dynamics in a wet tropical Forest. Ecosystems 17:918-930

Sall S, Bertrand I, Chotte JL, Recous S (2007) Separate effects of the biochemical quality and $\mathrm{N}$ content of crop residues on $\mathrm{C}$ and $\mathrm{N}$ dynamics in soil. Biol Fertil Soils 43:797-804

Sato T, Ezawa T, Cheng W, Tawaraya K (2015) Release of acid phosphatase from extraradical hyphae of arbuscular mycorrhizal fungus Rhizophagus Clarus. Soil Sci Plant Nutr 61:269-274

Schmidt MWI, Torn MS, Abiven S et al (2011) Persistence of soil organic matter as an ecosystem property. Nature 478:49-56

Silver W, Miya R (2001) Global patterns in root decomposition: comparisons of climate and litter quality. Oecologia 129: 407-419

Simard SW, Beiler KJ, Bingham MA, et al (2012) Mycorrhizal networks: Mechanisms, ecology and modelling. Fungal Biol Rev 26:39-60

Solly EF, Schöning I, Boch S et al (2014) Factors controlling decomposition rates of fine root litter in temperate forests and grasslands. Plant Soil 382:203-218

Soudzilovskaia NA, Douma JC, Akhmetzhanova AA et al (2015) Global patterns of plant root colonization intensity by mycorrhizal fungi explained by climate and soil chemistry. Glob Ecol Biogeogr 24:371-382

Steinaker DF, Wilson SD (2008) Scale and density dependent relationships among roots, mycorrhizal fungi and collembola in grassland and forest. Oikos 117:703-710

Strahler AN (1957) Quantitative analysis of watershed geomorphology. Trans Am Geophys Union 38:913-920

Sun Y, Gu J, Zhuang H et al (2011) Lower order roots more palatable to herbivores: a case study with two temperate tree species. Plant Soil 347:351-361
Sun T, Mao Z, Dong L et al (2013) Further evidence for slow decomposition of very fine roots using two methods: litterbags and intact cores. Plant Soil 366:633-646

Sun T, Dong L, Mao Z (2015) Simulated atmospheric nitrogen deposition alters decomposition of ephemeral roots. Ecosystems 18:1240-1252

Sun T, Dong L, Zhang L et al (2016) Early stage fine-root decomposition and its relationship with root order and soil depth in a Larix Gmelinii plantation. Forests 7:234

Sun T, Björn B, Lili D et al (forthcoming) Fast in, slow out - the underestimated role of root tip decay in soil $\mathrm{C}$ dynamics. Proc Natl Acad Sci U S A

Talbot JM, Treseder KK (2012) Interactions between lignin, cellulose, and nitrogem drive litter chemistry - decay relationships. Ecology 93:345-354

Talbot JM, Allison SD, Treseder KK (2008) Decomposers in disguise: Mycorrhizal fungi as regulators of soil $\mathrm{C}$ dynamics in ecosystems under global change. Funct Ecol 22:955-963

Terrer C, Vicca S, Hungate BA et al (2016) Mycorrhizal association as a primary control of the $\mathrm{CO} 2$ fertilization effect. Science 353:72-74

Thomas DC, Zak DR, Filley TR (2012) Chronic N deposition does not apparently alter the biochemical composition of forest floor and soil organic matter. Soil Biol Biochem 54:7-13

Tong J, Wenhua X, Cong L et al (2012) Tree species effects on fine root decomposition and nitrogen release in subtropical forests in southern China. Plant Ecol Divers 5:323-331

Tripathi SK, Sumida A, Shibata H et al (2006) Leaf litterfall and decomposition of different above- and belowground parts of birch (Betula ermanii) trees and dwarf bamboo (Sasa Kurilensis) shrubs in a young secondary forest in northern Japan. Biol Fertil Soils 43:237-246

Vaario LM, Heinonsalo J, Spetz P, Pennanen T, Heinonen J, Tervahauta A, Fritze H (2012) The ectomycorrhizal fungus Tricholoma matsutake is a facultative saprotroph in vitro. Mycorrhiza 22:409-418

Valenzuela-Estrada LR, Vera-Caraballo V, Ruth LE, Eissenstat DM (2008) Root anatomy, morphology, and longevity among root orders in Vaccinium Corymbosum (Ericaceae). Am J Bot 95:1506-1514

Valverde-Barrantes OJ, Freschet GT, Roumet C, Blackwood CB (2017) A worldview of root traits: the influence of ancestry, growth form, climate and mycorrhizal association on the functional trait variation of fine-root tissues in seed plants. New Phytol. https://doi.org/10.1111/nph.14571

van Dam NM, Bouwmeester HJ (2016) Metabolomics in the Rhizosphere: tapping into belowground chemical communication. Trends Plant Sci 21:256-265

Verbruggen E, Jansa J, Hammer EC, Rillig MC (2016) Do arbuscular mycorrhizal fungi stabilize litter-derived carbon in soil? J Ecol 104:261-269

Vogt KD, Vogt D, Grower ST, Grier CC (1990) Carbon and nitrogen interactions for Forest ecosystems. In: Pearson $\mathrm{H}$ (ed) the above- and belowground interactions in Forest trees in acidified soils. Commission of the European Communities. Directorate-General for Science, Research and Development. Environment research Programme, Brussels, pp 203-235

Wang KH, McSorley R, Marshall AJ, Gallaher RN (2004) Nematode community changes associated with 
decomposition of Crotalaria Juncea amendment in litterbags. Appl Soil Ecol 27:31-45

Wang Z, Guo D, Wang X et al (2006) Fine root architecture, morphology, and biomass of different branch orders of two Chinese temperate tree species. Plant Soil 288:155-171

Wang H, Liu S, Mo J (2010) Correlation between leaf litter and fine root decomposition among subtropical tree species. Plant Soil 335:289-298

Wang JJ, Tharayil N, Chow AT et al (2015) Phenolic profile within the fine-root branching orders of an evergreen species highlights a disconnect in root tissue quality predicted by elemental- and molecular-level carbon composition. New Phytol 206:1261-1273

Wardle D, Bardgett RD, Klironomos JN et al (2004) Ecological linkages between aboveground and belowground biota. Science 304:1629-1633

Watkinson SC, Boddy L, Burton K, et al (2005) New approaches to investigating the function of mycelial networks. Mycologist 19:11-17.

Went FW, Stark N (1968) The biological and mechanical role of soil fungi. Proc Natl Acad Sci U S A 60:497-504

Xia M, Guo D, Pregitzer KS (2010) Ephemeral root modules in fraxinus mandshurica. New Phytol 188:1065-1074

Xiong Y, Fan P, Fu S et al (2013) Slow decomposition and limited nitrogen release by lower order roots in eight Chinese temperate and subtropical trees. Plant Soil 363:19-31
Yang YS, Chen G-S, Guo J-F et al (2004) Decomposition dynamic of fine roots in a mixed forest of Cunninghamia Lanceolata and Tsoongiodendron odorum in mid-subtropics. Ann For Sci 61:65-72

Zadworny M, McCormack ML, Rawlik K, Jagodziński AM (2015) Seasonal variation in chemistry, but not morphology, in roots of Quercus Robur growing in different soil types. Tree Physiol 35:644-652

Zadworny M, Mccormack ML, Zytkowiak R et al (2016) Patterns of structural and defense investments in fine roots of scots pine (Pinus sylvestris L.) across a strong temperature and latitudinal gradient in Europe. Glob Chang Biol 23:1218-1231

Zeglin LH, Kluber LA, Myrold DD (2013) The importance of amino sugar turnover to $\mathrm{C}$ and $\mathrm{N}$ cycling in organic horizons of old-growth Douglas-fir forest soils colonized by ectomycorrhizal mats. Biogeochemistry 112:679-693

Zhang X, Wang W (2015) The decomposition of fine and coarse roots: their global patterns and controlling factors. Sci Rep 5:9940

Zhang D, Hui D, Luo Y, Zhou G (2008) Rates of litter decomposition in terrestrial ecosystems: global patterns and controlling factors. J Plant Ecol 1:85-93

Zobel RW (2016) Fine roots - functional definition expanded to crop species? New Phytol 212:310-312 